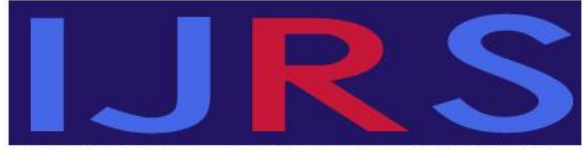

- INTERNATIONAL JOURNAL OF ROMA STUDIES .
Hipatia Press

www.hipatiapress.com

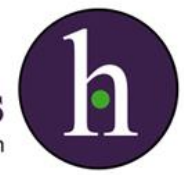

Instructions for authors, subscriptions and further details:

http://ijrs.hipatiapress.com

\title{
A Game of Thrones: Power Struggles and Contestation in Romani Studies
}

Andrew Richard Ryder ${ }^{1}$

1) Corvinus University of Budapest. Hungary

Date of publication: September $15^{\text {th }}, 2019$

Edition period: September 2019 - March 2020

To cite this article: Ryder, A. R. (2019). A Game of Thrones: Power Struggles and Contestation in Romani Studies. International Journal of Roma Studies, 1(2), 120-143. doi: 10.17583/ijrs.2019.4197

To link this article: http://dx.doi.org/10.17583/ijrs.2019.4197

\section{PLEASE SCROLL DOWN FOR ARTICLE}

The terms and conditions of use are related to the Open Journal System and to Creative Commons Attribution License (CCAL). 


\section{A Game of Thrones: Power Struggles and Contestation in Romani Studies}

Andrew Richard Ryder

Corvinus University of Budapest

\section{Abstract}

This article explores the relationship between the academy and Roma communities and reflects on how horizontal violence, commodification and scientism have created disconnection and forms of marginalisation. The article also reflects upon the emergence of a new cadre of critical Romani Studies researchers challenging the established hierarchies of the academy. The paper assesses the strength and validity of these challenges and reflects on whether merely new power elites are being formed or whether critical approaches to Romani Studies presents scope for transformative change. A version of the paper was presented at the Central European University Romani Studies summer school by the author in 2016 and 2017.

Keywords: Critical Research; Scientism; Participatory Research;

Intersectionalism; Transformative Change 


\title{
Juego de Tronos: Luchas de Poder y Contestación en los Estudios Romaníes
}

\author{
Andrew Richard Ryder
}

Corvinus University of Budapest

\section{Resumen}

Este artículo explora la relación entre la academia y las comunidades romaníes y reflexiona sobre cómo la violencia horizontal, la mercantilización y el cientificismo han creado desconexión y formas de marginación. El artículo también reflexiona sobre la aparición de un nuevo cuadro de investigadores críticos de los estudios romaníes que desafían las jerarquías establecidas de la academia. El documento evalúa la fuerza y la validez de estos desafíos y reflexiona sobre si se están formando simplemente nuevas élites del poder o si los enfoques críticos de los estudios romaníes presentan posibilidades de cambio transformador. El autor presentó una versión del documento en la escuela de verano de Estudios Romaníes de la Central European University en 2016 y 2017.

Palabras clave: Investigación crítica; Cientificismo; Investigación participativa; Interseccionalismo; Cambio transformador 


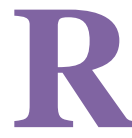

omani Studies, is an academic discipline which encompasses fields such as sociology, anthropology, linguistics and political science and can be termed an interdisciplinary subject. The article focuses on the emergence of a new cadre of critical Romani Studies researchers challenging the established hierarchies of the academy. The article assesses the strength and validity of these challenges and reflects on whether merely new power elites are being formed or whether critical approaches to Romani Studies presents scope for transformative change.

In the 1960s and 70s a strong sense of fraternity is said to have existed amongst scholars working in the field of Romani Studies, despite different philosophical outlooks this small band of researchers may have forged a working and constructive form of dissensus and support because their small numbers left them isolated in the academic world. Isolation which was accentuated by Romani Studies being deemed as a topic at the edges of legitimate study by some in the academic world (Acton, 1974). In recent years there has been an exponential increase in interest in Romani Studies, reflecting in part the fact that the issue of the Roma has risen up the political agenda as centres of power have sought to control, assimilate or more benignly raise the inclusion of a group that remains within European culture perhaps the ultimate pariah group. Consequently, centres of power have taken a growing interest in knowledge production in this area as decision makers have sought answers or, more often than not, support and legitimacy to shape and fashion policy responses.

In the early 1970 s there were relatively few active researchers working with a principal research interest in Roma communities. However, the European Academic Network on Romani Studies when established in 2011 was able to achieve a membership, in excess, of 400 members of which approximately 250 held $\mathrm{PhDs}$ (Stewart, 2017). Recent developments in this subject have centred on a series of fractious disputes and convulsions in which emerging scholars have challenged those who constitute an academic establishment (Ryder, 2018).

\section{The Growing Importance of Romani Studies}

The growing importance and value of Romani Studies to decision makers was reflected in the decision by the European Union and Council of Europe 
to support the European Academic Network on Romani Studies (EANRS). It was established in 2011 for initially two years to facilitate intercultural dialogue, promote the social inclusion of Roma and increase the visibility of existing research concerning Roma among the policy community and other stakeholders. It also aimed to support early career researchers and was steered by a Scientific Committee. A second stage from 2013 to 2015 focused more on funnelling expertise to guide policy makers in more informed decision-making and policy planning.

Tensions were created from the outset by the failure of the network to initially elect any Roma to the scientific committee, this led to calls for the network to be reconstituted and for new elections. Appeals for the EANRS to be reconstituted came primarily from critical researchers and Romani activists who denounced the existence of a non-Roma scientific committee as colonialist and reflective of a sense of academic elitism by established academics. Members of the scientific committee defended the status quo by arguing that they had been elected by their peers on the basis of recognised academic merit and to constitute the committee on any other basis might lead to the EANRS being held hostage to a narrow form of identity politics, which could be tokenistic and see Roma scholars prematurely propelled into lead positions by virtue of their ethnicity rather than ability.

The EANRS scientific committee offered a concession by allowing for a new election from the associate membership (non-PhD holders) and two Roma were elected to the scientific committee. Despite this concession critical Roma researchers and activists were not appeased, some felt an elite academic cabal was monopolising Romani Studies through control of the EANRS to bolster their own positions as advisors to decision makers and positions at the summit of the academic hierarchy. Some of these critical researchers and activists started to clamour behind calls for the establishment of a European Roma Institute (ERI).

The ERI proposal was zealously championed by the Roma Initiative Office at Open Society, a civil society initiative funded by the billionaire philanthropist George Soros, they actively used Soros's power elite connections. Soros had been able to accrue a network of influence on account of the important work Soros funded NGOs had achieved over two decades for Roma and was able to use this influence to lobby for the establishment of an ERI. The ERI has the institutional backing of the 


\section{Ryder-A Game of Thrones: Struggles in Romani Studies}

Council of Europe which together with Open Society Foundations funds and supports its operations, its primary aim is to promote Romani culture and the arts but also to offer advice and guidance to the Council of Europe. Critics asserted that the ERI was another instance of Soros being able to use his wealth and influence to shape and steer Roma policy at the highest levels. Another charge was that a small group of Roma hoped to benefit in terms of career progression from the opportunities that affirmative measures might offer. Matras (2015, para. 3), one of the chief critics in reflecting such sentiments, declared:

The small circle of young activists who have been pushing forward this agenda (and who launched an aggressive campaign last year against the committee of the European Academic Network on Romani Studies when it expressed concerns about plans for ERI) are hoping to fast-track their careers by getting influential jobs on the basis of their self-declared Romani ancestry, without having to produce a track record of many years of either leadership in human rights campaigns or contributions to scholarship. They wish to benefit from the stream of European funding for Roma-projects for years to come, and they want to be able to mimic the recognised scholarly authority of eminent researchers.

Tensions around the ERI were accentuated by the fact that the Council of Europe and European Union decided to cease funding for the EANRS beyond 2015. In addition, the Council of Europe decided to cease funding the European Roma Traveller Forum (ERTF). The ERTF was established in 2005 , it was funded by and had privileged access to the various bodies and organs of the Council of Europe which deal with matters concerning Roma and Travellers. It had a Secretariat in Strasbourg within the Council of Europe's premises. During the first year, elections for national delegates were organised in forty countries. The first Plenary Assembly was attended by 67 delegates from 33 countries. Supporters of the ERTF asserted it had democratic legitimacy by virtue of representation being based on elections. However, there were counter-arguments which claimed that the ERTF merely had the veneer of democracy, critics claimed in a number of countries largely self-appointed Roma leaderships had wrested control of the forum which had failed to forge an effective link with Roma communities in a broad sense. The scientific committee of the EANRS decided to issue a 
statement to the Council of Europe which was critical of the concept of an ERI. The EANRS (2014, para. 8) statement declared:

The academic engagement with Roma culture belongs within universities. It deserves to maintain the same reputation as other serious academic disciplines. Only on that basis is it possible to produce knowledge that can inform policy and public attitudes in a reliable and transparent manner.

The statement provoked a sharp reaction. Some critical researchers argued that it displayed academic elitism and arrogance through the claim that the academy should be the privileged locus of Roma knowledge production (Ryder, 2015). A signed letter which included prominent supporters of the ERI called for the scientific committee to resign as they had, it was asserted, not behaved democratically by failing to consult the EANRS membership on the letter they had sent.

In March 2016 the tensions within Romani Studies appeared to be renewed when the council of Europe issued a new four-year Thematic Action Plan on Roma and Traveller Inclusion. Coinciding with the Action Plan the Council of Europe issued a press release (as cited in Matras, 2016, para. 1), which referred to: "awareness raising activities at a local level to help curb early or forced marriages, domestic violence, trafficking and forced begging in Roma communities by addressing negative consequences of such activities".

This press statement was interpreted as playing to the gallery and anti Roma sentiments and was roundly condemned. In addition, nearly 100 academics, working in Romani Studies and members of the European Academic Network on Romani Studies signed an open letter of protest (EANRS, 2016). The letter declared that the Council of Europe statement could be interpreted as suggesting that Roma have a pre-disposition to early marriage, violence, organised crime, and begging and that generalisations of the kind made in the statement risked strengthening prejudice rather than alleviating it.

In a blog which was written by Professor Yaron Matras (2016, para. 4), a prominent voice within the European Academic Network on Romani Studies, Matras declared with reference to the Council of Europe statement: 


\section{Ryder - A Game of Thrones: Struggles in Romani Studies}

While academics have taken a lead role in this particular debate, standing up against the wholesale portrayal of Roma as beggars and rapists, there has been deafening silence among the ranks of the more established Romani activist circles. This is not surprising, given the fact that Roma activists are in many cases direct beneficiaries of EU and Council of Europe funds and therefore have less freedom than academic colleagues to direct open criticism against influential European policy bodies.

Some interpreted these comments as criticism of the Roma who had coalesced around the ERI. Conversely, some asserted the Council of Europe Action Plan was right to seek to tackle oppressive behaviours within Roma communities.

These episodes provide insights into the position taking and factionalism of rival groups within Romani Studies. The outline of events also raises questions about the relationship between academics and centres of power. This article seeks to provide the reader with an understanding of the wider context of this furore.

\section{Factors behind the Furore in Romani Studies}

Such was the intensity and ferocity of the outlined tussles within Romani Studies that they can be described as a furore, a tumultuous uproar and commotion. Now that the dust has settled it might be an apt time to make some sense of these events but in the process of trying to understand we need to probe the history of Romani Studies and the philosophical positions of the factions ranged against each other.

The study of Roma communities' dates back to the eighteenth century. European scholars such as Johann Rüdiger (1782) and Heinrich Grellman (1783) were the first to explore Roma communities, through linguistic study they identified India as the country of origin. Reflecting the social and cultural mores of the time, that connection was used by Eurocentric observers like Grellman to explain perceptions of the Roma's so-called primitiveness and backwardness. It should also be noted that the Roma's nomadic lifestyle was also deemed to be contrarian and at odds with enlightenment principles and the growing power of the state.

By the late nineteenth century, the Gypsy Lore Society had been formed and through its journal a small but identifiable cadre of researchers, who 
focused on studying the language and folkloric traditions of Romani communities had emerged. These 'gypsylorists' felt Gypsies were in danger of losing their ancient traditions and would even perhaps soon disappear through intermarriage and assimilation. Critics argued that such research was hierarchical and outsider driven but also tainted by forms of romanticism typical of that time which falsely interpreted change as decline.

The first serious challenges to the Gypsy Lore tradition materialised in the late 1960s. Activist orientated researchers like Thomas Acton, Ian Hancock and Donald Kenrick emerged who questioned the distant and amateurish scholarship of the Gypsylorists (Ryder, 2015). These activist/scholars were willing to work within Romani identity politics and to use research and knowledge production to aid the emancipation of the Roma. However, this new cadre of scholars were in turn challenged by a group of researchers that emerged from the 1990s who were professionalised and used what they deemed as more rigorous approaches than their precursors. These researchers working in the scientific tradition were prominent in major research projects and professed to offer expertise in policy. Critics complained that there was a danger that these 'experts' were used by policy makers too much and were depriving civil society of a role to which they might be better suited to take up.

Critics have disparaged these researchers as 'neo-Gypsylorists' although more academic in their approach, as with the Gypsylorists they are deemed to be distant and hierarchical. However, in turn those dubbed as neoGypsylorists have denounced their critics as lacking scholarly detachment and expertise and academic integrity by virtue of their partisanship (Barany, 2002). It was the so called neo-Gypsylorists that were perceived to be in control of the European Academic Network on Romani Studies.

Resentment towards the established academic elite in Romani Studies had been gaining momentum for some time prior to the furore that shattered the EANRS. What were the causes of this simmering resentment? Michael Stewart (2017, p. 126) by his own admission acknowledges how the influential summer school and courses on Romani Studies, that he organised for a number of years at the Central European University, failed to adequately involve Roma as scholars and teachers. In addition, some critical thinkers felt that the research interests of the established academic elite appeared to be prioritised and accorded greater status - namely studies that 
provided ethnographical, anthropological and linguistic insights into Roma communities to the neglect of studies that might reveal deeper insight into policy failure and how the marginalisation of the Roma might be alleviated.

Offence was aroused by members of the academic establishment asserting that the emerging cadre of critical researchers were purveyors of a substandard form of knowledge production labelled as 'NGO Science', a form of research they claimed which was conducted by researchers located within civil society and lacking the expertise of academia or was merely accepted and published because the authors were themselves Roma. The proponents of these arguments also stated that such research was completely spurious relying on misleading and inaccurate statistical data to service a narrow inclusion paradigm that reified Roma as victims in need of integration/assimilation. What is more, it is claimed the authors of such research are part of a 'Gypsy industry' which profits from the marginalisation of the Roma and thus have no real interest in solving the problems these communities face (Marushiakova-Popova \& Popov, 2017).

Many of the emerging critical thinkers in Romani Studies had started in civil society and later progressed to doctoral research and maintained in this progression a social change and policy interest. It would be unfair to castigate all this work as untrained 'NGO science or for that matter to claim that knowledge production emanating from civil society is worthless. In response to the charge of a 'Gypsy industry' it may be true that at times Roma civil society has been driven by narrow inclusion and donor driven agendas but to claim they have an interest in maintaining Roma exclusion is an extreme position to forward. In addition, the academic establishment of Romani Studies in making such criticism reveal their ignorance of the interconnections that can exist between policy, practice and academic outputs. Furthermore, despite the weakness of collected data, often stemming from weak governmental ethnic monitoring systems, many of the reports produced by civil society using what data is available have produced a convincing picture of the high levels of exclusion facing most Roma today. Such reports have been the engine for prompting the EU and governments to take some action. Although resulting actions to date may have been limited it should be noted that without civil society knowledge production and advocacy the awareness of Roma exclusion would be much more limited but also the potential to meaningfully transform policy agendas. 
Tensions were also aroused by the insinuation of the academic elite and their younger acolytes that the emerging Roma scholars were somehow no longer 'real Roma' now living a privileged existence often outside the 'ghetto' and indeed not accepted by the 'ghetto', a viewpoint which perhaps betrays a rather limited conception of ethnic identity failing to appreciate the ability and propensity of ethnic groups to innovate and adapt. Stewart (2017, p. 141) reveals something of these sentiments when he contends with reference to two emerging critical Romani scholars: "Moreover, they have suffered from a double discrimination - rejected as sell-outs, 'not real Rom' by traditional communities and even more thoroughly rejected by white society as "not real whites"'.

The dispute in Romani Studies between critical and more established scholars primarily centres on the nature of the relationship between the researcher and the researched and reflects longstanding tensions between scientism, the belief that the researcher should retain what is considered as objectivity and distance and the principles of embodied research. For Descartes (1641), knowledge constitutes a form of dualism, the knowing subject and the known object, an enlightenment philosophy labelled by some as scientism. Scientism exalts 'objectivity' and detachment from the researched. In contrast embodied knowledge is a research approach grounded in the reality of everyday life and which gives recognition to grounded and localized knowledge (Weiler, 2009).

Scientism puts a high value on 'pure' science in comparison with other branches of learning or culture (Sorrell, 2002). In his recent article on knowledge production in Romani Studies, Stewart (2017, p. 137) is proud to proclaim his adherence to research "on" the Roma (scientism) but to its critics it is a paradigm that has been nurtured by an individualist, industrialcentric society and has commodified research, squeezing out alternative forms of knowledge (Kovach, 2005). Code (1991) argues that science-based epistemologies are inherently anti-feminist not just by virtue of being hierarchical but also because they lack empathy and standpoint. Indeed, critics contend that such positivist thinking is deeply conservative, adopting quasi-scientific methods and conceptions of detachment, and that the pursuit of objective truth is delusional (Mies, 1983).

Furthermore, the authors of such research, who in Romani Studies are often white and come from privileged backgrounds, argue like Stewart 
(2017, p. 137) that their 'objective' research can gain deep insights into how communities work, descriptions which others might make use of to change society. To the chagrin of the critical thinker in Romani Studies though the academic establishment in this field fails to enter into a process of reflexivity where notions of critical whiteness prompt researchers to question how privilege and hegemony might shape and influence their interpretation of the lifeworld of Roma. The failure of such authors to critically reflect on how their background and cultural chemistry might shape and distort their perspectives stems from the perception that they are the 'all knowing', detached and measured scientist and observer. Critical researchers contend that research should be situated in the concerns of marginalized people (Harding, 1991). Standpoint theory contends that scientism in research cannot detach itself from the class, culture and race of the researcher, though recognition of their impact through reflexivity reduces the influence of bias (Reinharz, 1997).

Descartes (1641) as noted above was a lead proponent of scientism, he contended that knowledge was based on a form of dualism, namely the knowing subject and the known object, this can be termed as an enlightenment philosophy which glorified objectivity and thus countenances that in the pursuit of this goal research should be somewhat detached as it is asserted 'that getting too close' to those being researched may lead to bias (Smith, 2003). An example of the dangers of hierarchical relations in social inquiry is evidenced by the case of classic anthropology in which the outsider observer colonised knowledge and perceptions of indigenous groups. Thus, research becomes a 'one way process' in which the observed, for instance indigenous communities, are excluded from the process of knowledge production (Scheyvens \& Storey, 2003). Today some researchers may maintain such detachment and disinterest in the name of objectivity but it should be viewed as a continuation of the positivist tradition. Critical researchers influenced by postcolonial theory have challenged the notion that framing theory should be solely based on the thoughts of academics but instead incorporate the voices and experiences of the oppressed. Critical research, it is said, brings the researcher closer to a more valid and meaningful form of knowledge and it is argued is more ethical for those being researched as forms of accountability are developed at all stages of the research including involvement in analysis and interpretation. 


\section{Critical Romani Studies}

As outlined at the start of the paper the last decade has witnessed a major increase in the number of scholars interested in and working within the sphere of Romani Studies. Within the wave of new recruits there has been a number of critical researchers, some are from the Roma community and or have a background of activism in civil society. These critical researchers are particularly interested in research and activism which addresses social inequities and power differentials; they favour methodologies centred on change and participatory research and feminism. These approaches to research brought the critical researchers into conflict with the Romani Studies establishment, in particular the claims by the academic establishment to be the proponents and champions of more objective research.

For the critical researcher, what scientism labels as the 'truth' is both contested and politicised. For Foucault (1991) power permeates everything and is diffused in discourse, knowledge and 'regimes of truth', i.e. types of knowledge and discourse which are given the status of truth by those in power, which includes those who portray themselves as the 'all knowing expert' and is part of the controlling framework of hegemony. In what has been termed as counter-hegemonic action, not only are the intellectual elite capable of developing critical consciousness but so are those at the margins, what Gramsci described as 'organic intellectuals'. Gramsci's theory is evident within Freire's (1971) conception of critical pedagogy and participatory action research. These approaches take as a starting point the experiences of those at the margins but seek to expand their understanding of those experiences and link them with deeper perceptions, which connect immediate marginalisation with wider structural factors, but also prompt a desire for transformative action. As a consequence, critical researchers within Romani Studies have sought to empower and give voice to Roma communities (Ryder, 2017).

The Roma Research and Empowerment Network (RREN), formed in 2010, was a product of the growing interest in critical research. It was established in Budapest by a group of critical researchers, some were based in Roma NGOs and some were academics at an early stage of their academic career studying for PhDs or relatively new to university lecturing but with a 
background in Roma activism. The majority of the group were Roma. The RREN sought to promote participatory research and grassroots activism by hosting seminars and conferences in community venues. If staged within universities, such events were open to and targeted a mixed audience of researchers and community workers. The Network provided a platform and vehicle for a range of civil society workers and academics sometimes constrained in their activism by institutional limitations created within large NGOs and universities. Large NGOs tend to be rather corporate and hierarchically driven by work plans devised by chief executive officers and their boards while universities which are shy of political controversy and increasingly driven by business models are also not always the ideal environment for radical sentiments to be shaped and directed.

The RREN being no more than an informal network without funding or formal statutes liberated participants and enabled them to explore topics and ideas which might not be in complete tandem with those of the institutions where they worked. For example, some of the RREN activists were working within international NGOs and felt restricted by the hierarchicalism and bureaucracy of these NGOS which seemed to stifle independent and critical thought. As is often the case with strategic advocacy NGOs, often underresourced and stretched in meeting the demands made upon them, there seemed to be a disconnection with Roma communities.

In some respects, Budapest offered an ideal location for such a network as many large and established Roma NGOs were located there and from these a number of participants and contributors to the RREN were found. However, Budapest may have pulled the RREN too close to the orbit of the international NGOs through funding some of its ventures such as conferences and the fact that some leading lights of the RREN were connected in their jobs to these institutions or were dependent on their financial support. Did this subvert the aims of the RREN?

On the other hand, has the RREN subverted the culture of these Roma focused international NGOs? A number of these international NGOs have funded events organised by the RREN such as the 'Nothing About Us Without Us?' seminar and conference in 2014 which provided an important deliberative event for critical and emerging activist-researchers. The papers and ideas presented were further explored and elaborated in a special edition of the European Roma Rights Journal 'Roma Rights' (Ryder et al, 2015). 
The aforementioned conference and journal provided an important platform for discussion. Discussions centred on the role Roma should play in radical social movements and research and included calls for decision makers and NGOs to genuinely connect with Roma communities. It also called for a more intersectional agenda embracing feminism and LGBTQ rights and radical conceptions of social justice to be embraced in the campaign for Roma rights.

The collection of researchers and activists gathered around the RREN had differing views about the European Roma Institute (ERI) and the relationship they should hold with this institute. Some were fearful that links with institutional power might subvert the autonomy of critical research and activism. Others though felt that such an institute might offer a strong European platform which could enable Roma community leadership to articulate a counter-narrative to forms of anti-Gypsyism which might become even sharper during a time of political and economic turbulence in Europe.

Others were lukewarm in their support of the ERI and feared that with the end of funding for the European Roma and Travellers' Forum (ERTF) a vacuum might exist in terms of dialogue between decision makers and Roma communities. The ERTF though also had its critics with some concerned it merely gave a democratic veneer to self-appointed Roma leaders, who were traditionalist in their outlook. All the same some felt uneasy that a channel of communication between Roma communities and centres of power based in principle on democratic representation was being replaced by an entity where the representative process appeared to be less transparent, broad and direct. A number of critical thinkers in Romani Studies were also concerned by the initial appeals of the supporters of the ERI for that institution to have 'licensing' powers and influence over which academic centres might receive support and funding for Roma Studies. The fear was this might prompt forms of monopolisation and hierarchy which might repeat the mistakes of those imbued with scientism working within Romani Studies. This proposal appears to have been abandoned.

Differences have emerged in the cadre of critical Romani Studies with one group closely aligning themselves to the ERI and the newly established programme of Romani Studies at the Central European University (CEU) which is publishing a new open access journal of Critical Romani Studies. 


\section{Ryder-A Game of Thrones: Struggles in Romani Studies}

Matras (2017, p. 119) denounced this initiative with its alleged emphasis on political empowerment as turning the CEU into a "sponsored advocacy centre". Such a statement it could be argued fails to acknowledge the important contribution of ethnic and indigenous focused departments in universities in Canada, the USA, Australia and New Zealand which the CEU might potentially emulate.

Dissenting critical voices fear though that an overt reliance on university structures and academic approaches might lead to what Bhabha (2004) described as forms of 'mimicry' in which the colonized subvert the colonizers but there is the danger of them being ultimately shaped and transformed by the new institutions that they enter. For the dissenters rather than ape the established traditions of academia they contend the critical thinker should be engaged in a disruptive process, aimed at promoting unsettling truths and challenges, including the positive aspects of what it means to shape and produce knowledge outside of the academy or the rigid pathways it proscribes, valuing the voices of those who can be described as 'experts by experience' the subaltern (Ryder, 2017). Critical researchers believe that listening to the subaltern can align the traditions of community knowledge production with those of the university and civil society through forms of collaboration based on participatory action research where the three groups can be afforded space in research design, data collection and interpretation.

Stewart (2017, p. 126) indicates that there is a move by critical thinkers to privilege knowledge production by the Roma “...advocates of this approach have suggested that those who speak may be more important than what they have to say". This is a misinterpretation of efforts to understand and gain insight into real and lived experience. Sadly, the opportunities for innovative and participatory research where community 'voices' can be recognised are slight, constrained by budgetary limitations and or the narrow stipulations of the funder. In some cases, 'participation' and 'empowerment' in such projects become empty and hollowed out through tokenism and superficial forms of engagement which seek to dress up paternalism or consultation as co-production and collaboration. Funding regimes which are more generous and allow communities greater agency in the research process could through localised community profiles, where communities assess their situation, needs and questions to be posed with other forms of 
participatory research, do much to make the European Union's goal of Community Led Local Development a reality for Roma communities.

Another reason that the dissenting critical thinkers of Romani Studies are increasingly hesitant about an over reliance on the academy is that the growing commodification of research and higher education might not make the academy the ideal place to locate the mouthpiece of the critical Romani voice. The traditional professional culture of open academic debate and inquiry is being increasingly replaced by a stress on measured productivity. Universities have become like corporations with formulae, incentives and targets guided by the principles of 'new managerialism' (Miller, 2010). Academia can in fact be viewed as a field of power dominated by an audit culture which exalts and promotes the 'competitive academic', adept at selfpromotion, voluminous publication in top academic journals and the acquisition of grants (Sparkes, 2007). It has been said that the contemporary university has changed from a platonic academy to a commercial mall (Wood, 2010).

Academics have become competitors in a market - less inclined to acknowledge and respect the views and aspirations of one's competitors but also less likely to forge genuine links with the researched. In part such distancing will be prompted by time and resource factors as the 'managed' academic and researcher race to complete the task within the agreed budget and timeframe but such distancing will also be prompted by the desire to win the contract.

Inclusive and genuinely critical research gives those being researched a 'voice' and is more likely to challenge the status quo and perceived wisdom of power elites. Despite the value of inclusive research approaches those engaged in the commissioning of research and policy makers are more likely to commission research shaped by scientism and or tokenistic forms of engagement with the researched. It may also be the case that some universities who have or seek EU funding for research are tamed in their critique by a need and dependency for funding. Hence, the genuine voice of the critical thinker may be best served by being located outside the academy or is at least not too closely aligned to the structures and ethos that constrain critique and challenge. This may though be a difficult and barren career path in the present political and institutional context that some critical researchers find themselves in. 


\section{Conservers and Heretics}

The critical researchers who are supporting the ERI and the new journal of critical Romani Studies could be described as proponents of affirmative sabotage, basically using the master's tools or machine to dismantle/ruin the master's house/machine. Such a course could be described as making change and presenting challenge from the inside and in terms of Roma academics could be comparable to the process within Indigenous Studies in North America, Australia and New Zealand.

However, such a strategy could be fraught with risk. The Black lesbian feminist write Audre Lorde (2007) felt there was a danger of tokenism in such a stratagem and argued narrow binary thinking which could be a feature of affirmative identity politics precluded a more intersectional understanding of the world which was a prerequisite to transformative change. A key point though was the use of such tools might not bring about concrete change for they worked in parallel and in tandem with existing structures of power. For Lorde the utilisation of tools of patriarchy or hegemony by those who are ostensibly radicals would merely subvert transformative change. As Lorde (2007, p. 2) notes in the aforementioned text "They may allow us temporarily to beat him (the master) at his own game, but they will never enable us to bring about genuine change".

Thus, there are dangers of critical voices succumbing to the machinations of institutional power, under the pretext and justification of affirmative sabotage but inevitably there is a danger of tokenism and the structures of power rather than being dismantled or transformed are in effect bolstered. Lorde encourages us to ponder and reflect on the value of new tools, for me if critical Roma research and activism is to have value those tools need to be premised on intersectional alliance building but also reach out to the margins in that process and empower, give voice and to act as critical catalysts. To return again to Indigenous scholarships there have been occasions where counter-hegemonic discourse has incorporated the structures, categories and premises of hegemonic discourse (Sefa Dei, 2002). Thus, there is a danger of counter-hegemonic discourse becoming hegemonic. Could this be the fate of critical Roma studies?

The challenges to a positivist academic establishment and in turn emergence of a new critical group of researchers to some degree becoming a 
new establishment could be redolent of the struggles Bourdieu (1988) described in his seminal work on academic politics 'Homo Academicus'. Bourdieu describes disputes within the academy as being positioned between the 'conservers' (orthodoxy) and those with a more subversive disposition (heretics). The field of academic discipline is in fact in permanent conflict which can be epic, intense and emotive, as academics engage in strategies or "position taking" directed towards the maximizing of symbolic gain (Swartz, 1997). The epic scale of struggles and contests within Romani Studies has prompted the author of this article to refer in the title to 'A Games of Thrones' the popular fictionalised account of power struggles. In recent debates in Romani Studies, as described in this paper, we may have seen some of the heretics to a degree come near to rivalling the conservers in part by virtue of their relations with power and by status and platforms secured.

Bourdieu (1991) described a field as a structured system of social positions which is occupied by individuals or institutions. Its nature defines the situation of its occupants. Moreover, Bourdieu said the field is an arena where struggles and contests occur over the distribution of resources. Positions within the social field are determined by the relationship of domination, subordination or equivalence as a consequence of the access they provide to capital.

The academic world I depict can certainly be described as a social field characterised by struggles to maintain or gain control and status and forms of power and it is almost certain that the paradigm shift I describe has taken place by virtue of the political and institutional power and resources that a collection of Romani critical researchers have been able to mobilise. This power might provide a platform and impetus for real change, on the other hand there might be a risk of dilution and compromise. In defence of the Roma scholars willing to work within and through institutions it might be fair to wonder whether it is naïve and self-defeating not to recognise the value of being able to mobilise resources for change and accept the political reality and logic of seeking to radically change the system from within.

Kuhn (1962) describes in his conception of paradigm change how following a process of flux and contestation that the process reaches a revolutionary phase where a new power elite establishes mastery and dominance but in turn these triggers new challenges and the cycle of change and challenge starts again. This may be a process we have recently 


\section{Ryder-A Game of Thrones: Struggles in Romani Studies}

witnessed in Romani Studies. Struggles between conservers and heretics are not confined to Romani Studies, we live in an age of anxiety, frustration and challenge as evidenced by the political and social challenges to the status quo in Brexit, the premiership of Boris Johnson and presidency of Donald Trump and growth of populism and in turn xenophobia, nativism and antiGypsyism, further convulsions are likely. In this time of flux and tumult critical researchers are striving to make their research and activism relevant to the times in which they live.

The academic establishment suggest that critical Romani studies researchers feel they are morally superior by virtue of their approach to knowledge production (Matras, 2017; Stewart, 2017). Critical researchers have like their more established peers, a diverse and complex range of motivations prompting them in their work and strategies as to how to disseminate their work and maximise impact, with some actively seeking to align Romani struggles to radical transformative action. What might be mistaken as ideological fervour and or moral crusading is instead a sense of urgency propelled by the ascending crisis as exemplified by the extremism and polarisation of twenty first century life. A sense of urgency accentuated by the position some critical researchers are located in the field, increasing their proximity to the crisis or heightening their perception of the inherent dangers.

Critics argue that critical Romani studies researchers are seeking to transfer and transplant outlooks and frames, for example the viewpoints of North America race politics including critical race theory, and impose such strategic mindsets and interpretations on a distant and disparate group of Roma communities in say the Czech Republic or Hungary, far removed from the experiences of the US (Stewart, 2017). Critical Race Theory places a strong focus on the recognition of the experiential knowledge of excluded communities in defining their exclusion and is coupled with activist agendas which incorporate commitments to social justice and change and recognition that racism is a central factor in a social order which rests on intersectional oppressions including economic, racial and gender exclusion. Critical Race Theory and the broad principles it encompasses has been an important analytical tool for those working within critical Romani Studies despite its origins in North America (Ryder et al, 2014). It has been a catalyst to 
challenges to policy positions that are imbued with paternalism or tokenism and academic viewpoints shaped by scientism.

Stewart (2017, p. 141) is sceptical with reference to the intersectionalism of critical Romani Studies, arguing that it constitutes a "tragic cul-de-sac" with a "framework of one-sided descriptions of historical persecution and lamentations of white hegemony". Stewart though fails to appreciate that such intersectionalism despite his dismissive interpretation could be a nuanced tool which can garner fresh and valid insights into race, class and gender and the interplay between these variables. Intersectionalism is also a central factor in the strength of the new critical Romani studies allowing for a critique of internal group oppressions as opposed to idolising tradition facilitating the Roma in aligning with intersectional and broad movements for transformative change which challenge the cultural and structural causes of marginalisation in the 21st century. It allows critical researchers to gain insights into the crisis within neoliberalism and its efforts to reorient its path through hyperglobalism and in some cases alliances with radical conceptions of nationalism in the form of authoritarian populism but also the manipulation of identities to support or challenge hegemony. Critical activism sometimes leads to the introduction of new fames to communities and debates and deliberation as to how to interpret identity, in part this can contribute to what Spivak terms as 'strategic essentialism', the finding of common ground and forging of alliances. Intersectionalism thus allows for dialogue, flexibility and reflection and are qualities which are essential for inclusive identity formation. Critics of intersectionalism run the risk of repeating the mistakes of the Gyplorists by insinuating change and adaptation is redolent of decline or in this case the dilution of Romani identity.

Snow and Benford (1988) define collective action frames for social movements as holding three core tasks: diagnostic, prognostic, and motivational. Advocates for a grassroots orientated Roma social movement support action frames encompassing a narrative which understands and challenges the economic and ideological forces behind the current crisis in capitalism and austerity, which is intersectional in terms of drawing on all the ideas and talents of diverse sections within the Roma communities and seeks to form alliances with other marginalised groups. In the formation of a new and dynamic Roma social movement, participatory researchers and 
community-based activists and NGOs have the potential to perform the role of catalysts helping those at the margins to define the problems a community faces. In doing so they can formulate an understanding of causal factors and remedies, creating a 'counter-story' to challenge dominant discourses (Dixson \& Rousseau, 2005).

Localised activism can thus attempt to provide opportunities for activists to train and develop the requisite agency, self confidence, skills and knowledge. The process of critical pedagogy can be a long and intensive process involving not just skill development but trust formation. Indeed, this is where the established civil society organisations have often failed in their work with Roma through an inability to inspire and galvanise at the grassroots or act in a transparent and dialogic manner.

\section{Conclusion}

The emergence of critical Romani thinkers in the academy has, despite the initial tensions and disputes as outlined in this paper, done much to broaden the parameters of academic debate in Romani Studies. Such contestation is to be welcome for debate and difference is the engine of knowledge production. Much of this paper has mapped out and discussed debates and means by which the voice of Roma communities can be heard in knowledge production. Alfred (2004) notes with reference to Indigenous studies the process of 'Indigenizing' the university should be a disruptive process, aimed at promoting unsettling truths toward decolonization, including the positive content of what it means to be Indigenous, as well as criticisms of colonialism. These are sentiments which critical Romani thinkers need to bear in mind as its members ascend the hierarchy of the academic establishment.

What are the perceptions of the Roma community at the margins to these developments? I can only base the answer to this question on the comments I hear from my contacts and associates in the "ghetto" or living life at the margins who witnesses the headlines of the developments in Romani Studies through mediums like Facebook where they witness the release of a new book or article by a Romani author or the staging of an academic event featuring Romani scholars at prestigious universities like Oxford or Harvard. For some it is a source of great collective pride that members of their 
community are scaling the heights of academia, challenging prejudice, providing role models and bolstering support for the value of formal education. Some in the "ghetto" though appear to be bemused or such occurrences pass them by, such is the nature of their marginality. The great challenge for critical Roma thinkers, universities and funders will be to bridge that gap and through tools like participatory research involve the community even more in the design, data collection and interpretation of research projects and indeed debates and discussions as to the fate of the Roma in troubled times.

With reference to 'troubled times' namely the rise of authoritarian populism and corresponding demonisation of Romani communities there has been talk of the value of grassroots activitism and communication channels that can overcome establishment control of media and mainstream political discourse and bring about fundamental socio-economic and cultural change. Such a movement will need to learn from the failures of the Occupy Movement and whilst retaining the sense of democracy and fluidity of that movement develop forms of organisational structure that can properly sustain and direct a mass movement. However, the new movement needs to reach out beyond the constituencies mobilised by Occupy and find means to resonate and inspire those at the margins. In this sense the movement needs to accrue legitimacy by gathering at its core what Gramsci described as 'organic intellectuals', the marginalised non professional political class whose presence is needed to give any radical social movement with ambitions for transformative change a genuine chance to succeed in initiating bottom up rather than top down change. The Roma are one of the most marginalised groups in European society and present the ultimate pariah group for the ascendent forces of reaction. The Roma therefore have an important position in any new social movement which will be measured in terms of success by the notions of solidarity it can engender across the social spectrum but hopefully include those at the margins. Hence, it is imperative that the critical voice of Romani activism is autonomous and unrestrained in the strategic choices it needs to make in these deeply troubled times, this is a central message of this paper. Winter is not coming, it is here! 
140 Ryder-A Game of Thrones: Struggles in Romani Studies

\section{References}

Acton, T. (1974). Gypsy politics and social change. London: Routledge \& Kegan Paul.

Alfred, T. (2004). Warrior Scholarship: Seeing the University as a Ground of

Contention. In D. Mihesuah \& A. Cavender Wilson (Eds.),

Indigenizing the Academy (pp. 88-110). Lincoln, NB: University of

Nebraska Press.

Barany, Z. (2002). The East European Gypsies: Regime Change,

Marginality, and Ethnopolitics. Cambridge: Cambridge University

Press.

Bhabha, H. (2004). The Location of Culture. London: Routledge.

Bourdieu, P. (1988). Homo Academicus. Stanford, CA: Stanford University Press.

Bourdieu, P. (1991). Epilogue - On the Possibility of a Field of World Sociology. In P. Bourdieu \& J. Coleman (Eds.), Social Theory for a Changing Society (pp. 373-388). Boulder: Westview Press.

Code, L. (1991). What Can She Know? Ithaca, NY: Cornell University Press.

Descartes, R. (1641). Meditations on First Philosophy. In The Philosophical Writings of René Descartes, trans. by J. Cottingham, R. Stoothoff \& D. Murdoch. Cambridge: Cambridge University Press, 1984, vol. 2, pp. 1-62.

Dixson, A. D., \& Rousseau, C. K. (2005). And We Are Still Not Saved: Critical Race Theory in Education Ten Years Later. Race Ethnicity And Education, 8(1), pp. 7 -27. doi: 10.1080/1361332052000340971

EANRS. European Academic Network on Romani Studies. (2014).

Statement of the Scientific Committee on the Council of Europe's proposal for a European Roma Institute, 30 April 2014. Retrieved from http://romanistudies.eu/wpcontent/uploads/2015/02/RAN paper on ERI 30April2014.pdf

EANRS. European Academic Network on Romani Studies. (2016). Open Letter to the Secretary General of the Council of Europe. Retrieved 
from http://romanistudies.eu/news/open-letter-to-the-secretarygeneral-of-the-council-of-europe/

Freire, P. (1971). Pedagogy of the Oppressed. New York: Herder \& Herder. Foucault, M. (1991). Discipline and Punish: the birth of a prison. London: Penguin.

Grellmann, H. (1783). Historischer Versuch über die Zigeuner, betreffend die Lebensart und Verfassung, Sitten und Schicksale dieses Volkes seit seiner Erscheinung in Europa und dessen Ursprung. Göttingen: Dietrich.

Harding, S. (1991). Whose Science? Whose Knowledge? Thinking from women's lives. Ithaca, NY: Cornell University Press.

Kovach, M. (2005). Emerging from the Margins: Indigenous methodologies. In L, Brown \& S, Strega (Eds.). Research As Resistance: Critical, indigenous, and anti-oppressive approaches (pp.19-36). Toronto: Canadian Scholars' Press.

Kuhn, T. (1962). The Structure of Scientific Revolutions. Chicago: University of Chicago Press.

Lorde, A. (2007). The Master's Tools Will Never Dismantle the Master's House. In A. Lorde (Ed.), Sister Outsider: Essays and Speeches (pp. 110-114). New York: Random House \& Crossing Press.

Matras, Y. (2015). Why are they setting up a European Roma Institute. Circulated on the Romani Studies Network. Retrieved from http://www.romea.cz/en/news/world/commentary-why-are-theysetting-up-a-european-roma-institute

Matras, Y. (2016). The Council of Europe comes under fire from academics for reinforcing prejudice. Retrieved from http://romanistudies.eu/doroma-need-protection-from-themselves/

Matras, Y. (2017). Letter from the outgoing Editor. Romani Studies, 27(2), 113-123. doi: $10.3828 /$ rs.2017.7

Mies, M. (1983). Towards a Methodology for Feminist Research. In G. Bowles \& R. D. Klein (Eds.), Theories of Women's Studies (pp. 117139). London: Routledge \& Kegan Paul.

Miller, B. (2010). Skills for Sale: What is being commodified in higher education? Journal of Further and Higher Education, 34(2), 199-206. doi: $\underline{10.1080 / 03098771003695460}$ 
Marushiakova-Popova, E. \& Popov, V. (2017). Orientalism in Romani Studies: the case of Eastern Europe. In H, Kyuchukov \& W, New (Eds.), Languages of Resistance: Ian Hancock's Contribution to Romani Studies (pp. 8 -16). Lincom: Europa.

Reinharz, S. (1997). Who Am I? The need for a variety of selves in the field. In Hertz, R. (Ed.), Reflexivity and Voice (pp. 3-20). Thousand Oaks, CA: Sage.

Rüdiger, J. (1990). Von der sprache und herkunft der Zigeuner aus indien. In Neuester Zuwachs der teutschen, fremden und allgemeinen Sprachkunde in eigenen Aufsätzen (37-84). Hamburg: Buske.

Ryder, A. R., Rostas, I., \& Taba, M. (2014). 'Nothing about us without us': the role of inclusive community development in school desegregation for Roma communities. Race Ethnicity and Education, 17(4), 518539. doi: $10.1080 / 13613324.2014 .885426$

Ryder, A. (2015). Co-producing Knowledge with below the radar communities: Factionalism, Commodification or Partnership? A Gypsy, Roma and Traveller Case Study (University of Birmingham: Third Sector Research Centre Working Paper). Retrieved from https://www.birmingham.ac.uk/Documents/college-socialsciences/social-policy/tsrc/discussion-papers/2015/GTR-discussionpaper-g-ryder-research-co-production-case-study.pdf

Ryder, A, Bogdán, M, Dunajeva, K, Junghaus, T, Kóczé, A, Rövid, M, Rostas, I, Szilvási, M, \& Taba, M. (2015). 'Nothing about us without us? Roma participation in policy making and knowledge production'. Journal of the European Roma Rights Center, 2. Budapest: ERRC. Retrieved from http://www.errc.org/roma-rights-journal/roma-rights2-2015-nothing-about-us-without-us-roma-participation-in-policymaking-and-knowledge-production

Ryder, A. (2017). Sites of Resistance: Gypsies, Roma and Travellers in the Community, School and Academy. London: Trentham Press IOE (Institute of Education).

Ryder, A. (2018). 'Paradigm Shift and Romani Studies: Research 'On' or 'For' and 'With' the Roma'. In S, Beck and A, Ivasiuc (Eds.), Roma Activism: Reimagining Power and Knowledge (pp. 91-111). New York: Berghahn. 
Sefa Dei, G. (2002). Rethinking The Role of Indigenous Knowledges of the Academy. The research network for New Approaches to Lifelong Learning (NALL Working Paper 58).

Scheyvens, R., \& Storey, D. (2003). Development Fieldwork: A Practical Guide. London, Sage.

Smith, A. (2003). Routledge Philosophy Guidebook to Husserl and the Cartesian Meditations. London \& New York: Routledge.

Snow, D., \& Benford, R. (1988). Ideology, Frame Resonance, and Participant Mobilization. In B. Klandermans, H. Kriesi \& S. Tarrow (Eds.), From Structure to Action: Social Movement Participation Across Cultures (pp. 197-217). Greenwich, Conn.: JAI Press.

Sorrell, T. (2002). Scientism: Philosophy and the infatuation with science. London: Routledge.

Sparkes, A. C. (2007). Embodiment, academics, and the audit culture: A story seeking consideration. Qualitative research, 7(4), 521-550. doi: $\underline{10.1177 / 1468794107082306}$

Stewart, M. (2017). Nothing about us without us, or the dangers of a closedsociety research paradigm. Romani Studies, 27(2), 125-146. doi: $\underline{10.3828 / \text { rs. } 2017.8}$

Swartz, D. (1997). Culture and Power - The Sociology of Pierre Bourdieu. Chicago: University of Chicago Press.

Weiler, H. (2009). Whose Knowledge Matters? Development and the Politics of Knowledge. In T. Hanf, H. Weiler \& H, Dickow (Eds.), Entwicklung als Beruf (pp. 485-496). Baden-Baden: Nomos.

Wood, F. (2010). Occult innovations in higher education: Corporate magic and the mysteries of managerialism. Prometheus, 28(3), 227-244. doi: $\underline{10.1080 / 08109028.2010 .518051}$

Andrew Richard Ryder is an Associate Professor at the Institute of Sociology and Social Policy at the Corvinus University of Budapest, Hungary

Contact Address: andrew.ryder@uni-corvinus.hu 